\title{
Chapter 9. From the Poetics of Place to the Politics of Space: Redefining Cultural Landscapes on Damer, Maluku Tenggara $^{1}$
}

\section{Sandra Pannell}

\section{Introduction}

For a number of years, the people of Amaya and Wulur, two villages respectively situated on the western and eastern coast of the island of Damer, have been locked in dispute over the line demarcating their adjoining territorial domains. Soon after my arrival (in 1986) this altercation reached one of the many climaxes in what has become a major struggle over the appropriateness and appropriation of certain forms of knowledge. Redefining the cultural landscape on Damer amounts to more than just shifting the position of boundaries. It shakes the very foundations of social identity, engendering as it does tectonic epistemological movements. As this idiom suggests, these social tremors have a spatial locus.

In his writing on spatial practices, Michel de Certeau (1984) finds it useful to distinguish place from space. Place, according to de Certeau, refers to the locational instantiation of what is considered to be customary, proper and even pre-established. Space, on the other hand, has none of this stability but instead is composed of the "intersections of mobile elements" (1984:117) which are ambiguous and often in conflict. In short, space is produced when place is risked or activated in practice. Space, as de Certeau points out, is thus "practiced place" (p.117). This distinction between place and space is analogous to the distinction between a map and an itinerary. One signifies the collective and ordered representations of the state of knowledge about the world, the other represents the actions or practices by which this knowledge is produced, affirmed or transformed. As a cultural geography, the landscape is both map and itinerary, place and space. This distinction between space and place, between itinerary and map, constitutes a useful heuristic device in understanding the redefinition of cultural landscapes on the island of Damer in eastern Indonesia.

In this paper, I explore the discursive practices that transform places into spaces and spaces into places. Stories, I argue, are instrumental in this play of changing relationships. On the one hand, they present in synoptic form the physical landscape as a cultural, and thus symbolic, geography; in this capacity they can be regarded as "models of reality" (see Geertz 1973:93-94). On the other 
hand, stories also labour to create what de Certeau refers to as geographies or "theatres of action" (1984:123) and, in this sense, they can be viewed as "models for reality" (see Geertz 1973:93-94). However, more than just reproducing and preserving what is perceived as already given, stories as forms of the "productive imagination" (Ricoeur 1986:xxx) also pave the way for an exploration of the possible and of the possibility of change. ${ }^{2}$ A consideration of the social redefinition of culturally constituted spatial boundaries on Damer highlights this dialectic between the pre-figured and the transfigured and points to the creative, conflictive and changing nature of the relationship between people, place, space and stories.

\section{The Poetics of Place: Constructing Maps}

In Amaya, narratives associated with the different uma ("house") groups represented in the village constitute one way in which knowledge of the landscape is constructed, disseminated and transmitted through time. More than just articulating the sum of this knowledge, Mayawo ("the people of Amaya") stories define and give form to a specific cultural landscape; a landscape criss-crossed by a multitude of significant pathways and punctuated with a number of noumenally important places. As such, it is more appropriate to speak of Mayawo narratives as "topostories" rather than as "histories". 3

Collectively, these pathways and named places signify the journeys taken by a number of anthropomorphic beings (the majority of which are regarded as allocthons, that is, they originated elsewhere) and the sites at which they stopped and performed acts of creation, transformation or destruction. The toponymic activities of these beings establish and authorize their status as other than human; humans are born into a world of ordered named places. They are not considered to possess the power to create places through the act of naming. The unique journeys of each of the beings and the places where they stopped serve to define a number of discrete topographic estates, which today are linked to the different "houses" in Amaya. Insofar as these topographic estates are encoded in narrative form, and given the constitutive importance of place to the identity of an uma, we can speak of local narratives as representing the "origin" stories for a particular "house". In a broader sense, the activities of the beings also served to establish the domains of the different village-centred groups on the island. Domain here is understood as extending beyond the terrestrial limitations of the island and thus incorporates the surrounding reefs, waters and off-shore islands. On this basis, the people of Amaya claim ownership of the western half of the island and associated reefs, of the coral atolls of Nus Leur approximately $25 \mathrm{~km}$ south-west of Amaya, and of the island of Terbang Utara situated some $10 \mathrm{~km}$ south of Damer. Terbang Selatan, the other island in this group, is contentiously claimed by people in the villages of Wulur and Kehli. The eastern half of Damer is variously divided between the seven other villages on the island. In the case 
of these other domains, ownership is again authenticated by the so-called "origin" narratives pertaining to each of these village-centred groups.

The landscape is thus culturally constructed and socially considered as a given; a pre-established, pre-figured order of territorial domains, localized estates and named places linked by identifiable tracks, immutably fixed in time and space. The landscape also serves as the empirical foundation for the veracity of Mayawo stories in the same way that the narratives establish the authenticity of the cultural geography - a recursive movement which inextricably links stories to the landscape, not merely as objects of knowledge, but as forms of knowing or epistemology. Considered as collective representations of what are regarded a priori as established orders of heterogeneous places, stories and the landscape constitute maps, they encode or embed that which is perceived as customary and cultural.

\section{The Politics of Space}

\section{Itineraries}

Mayawo narratives do more than just provide a model or map for understanding place - they also create itineraries or social ways of moving through this spatial and cultural landscape. In this sense, they can be viewed as travel stories and insofar as they are collective cultural representations, they can also be spoken of as, to borrow de Certeau's phrase, the "means of mass transportation" (1984:115). Not only do these narratives detail the adventures and wanderings of a number of different anthropomorphic beings but they also produce geographies of action for people in Amaya. The landscape, as a narrated and geographic text, thus signposts forms of social behaviour, rights, responsibilities and relations. The configuration of places, tracks and land which comprise a "house" estate and of the ancestral associations it has, for example, suggests who is associated with it, the nature of that association and its relational implications, plus the kinds of actions or codes of conduct appropriate in that context.

Thus, the poesis or creation of place which Mayawo narratives effect and recall is simultaneously a construction of social identity and social relatedness. Genealogies of place are also topogenies of people. Affiliation with place or with configurations of places represents more than just an adjunct to the anthropologically constructed social staples of kinship (primarily defined in terms of biological and genealogical relations) and social organization (so often predicated upon the notions of descent and marriage). In Amaya, identification with place(s) invests people with a number of meaningful social identities and constitutes the basis for understanding both social relatedness and the formation of social groups. ${ }^{4}$ For example, individuals born outside of the village and in the surrounding forests are named after the place of their birth. Given the 
associations between named places, estates and the social groups called uma, this name cogently signifies the uma affiliation of the individual as well as pointing to the people with whom he/she shares a common identity. More frequently, however, birth takes place within the context of the village. In this case, the place where a person is born is denoted by the incorporation of the name of an uma into a person's name. The names of uma or "houses" semantically encode and delineate certain constellations of places within the context of the village and metonymically point to the estates associated with each of the uma. Uma is thus a spatial construct which, in terms of one of its significations, refers to a physical residence or house. As I mentioned before, uma also signifies a group of people who participate in a shared identity on the basis of a common identification with one or more of a number of places which collectively comprise the discrete topogeny of an uma. This common affiliation to place(s), and thus "house", is primarily established by birth although there are other means, such as residence, by which an individual can establish a socially meaningful connection to place, to uma. Individuals also differentially identify with more inclusive groups termed ono. The four named ono in Amaya signify the four primary spatial divisions recognized in the village. Recruitment to an ono is informed by a person's identification with place and is mediated by a person's "house" affiliation which serves to signify this link. For instance, an individual is a member of Ono Atowcheyeni on the basis that he/she resides within the area associated with this ono, which in this case encompasses the land fronting onto the sea. Residence in this part of the village is structured by a person's "house" affiliation, "house" identity being inextricably embedded in place. Finally, the name of the village itself confers upon a person his/her most inclusive place-based social identity. This identity is grounded not only in the village as place but also signifies all of the places which collectively comprise the cultural landscape as a shared experience. Identification with place thus constitutes the basis for the construction of social relatedness (which may be expressed in a number of idioms including place, biological substance and genealogical propinquity) and, in this sense, expressions of identity and relatedness should be viewed as spatial practices. Thus place, in this understanding, not only has a noetic or knowledge-based value but also carries with it what Corbin (1969) calls an "imaginal" value in that it is constitutive of the fundamental ground of social reality.

It is this engagement of place, or the "practice of place", which produces what de Certeau defines as space: the social geography. Space is thus the actualization, by the operations of historical subjects, of what has already been created - place. This engagement of place not only produces space but also reproduces the conceptual ground which informs these practices; the so-called "structures of the long run", to borrow Marshall Sahlins's phrase (1981:9). However, as Sahlins points out, cultural categories are not merely reproduced, 
their reproduction also affects their transformation. In this respect then, space as realized place is analogous to Sahlins's notion of the "structure of the conjuncture", and as such is already a politicized domain. The politics of space are particularly well illustrated in relation to the marking out and maintenance of boundaries on Damer.

\section{Boundaries}

Returning to the dispute between the villages of Amaya and Wulur: this dispute concerns the position of the boundary between the domains of the two villages. The place presents a paradox; it is the point of difference between the two villages yet it also represents what they have in common. And what they share is the narrative that recounts the actions by which the boundary separating the two regions was established. This narrative constitutes the "origin story", or topogeny, with different emphases for the "house" of Newnuny in Amaya and for the "house" of Rohmode in Wulur. These narratives clearly articulate or, put differently, set in place the position of the boundary between the two territories. The empirical mark of this boundary is a river that separates the two beach sites of Odaro and Parano, respectively located in the domains of Amaya and Wulur. The river, flowing as it does into the sea, also cuts between the two islands of Terbang Utara and Terbang Selatan, so that Terbang Utara falls within the domain claimed by Amaya while Terbang Selatan is incorporated into the region owned by the residents of Wulur.

Notwithstanding their shared traditions and the empirical evidence which verifies the truth value of local narratives, people in Wulur assert that the boundary lies further west than that delineated in the narrative. By extension this assertion implies that they can also legitimately (in terms of the logic of the narrative, that is) claim the island of Terbang Utara as their own.

There is an economic logic which informs these claims. The reefs surrounding both Terbang Utara and Terbang Selatan are, or in the latter case were, rich with trochus shell. Having largely exhausted the trochus shell reserves on their own island, and spurred on by the high prices offered by the local Indonesian-Chinese traders, many people in Wulur have now taken to "stealing" the shell from the reefs surrounding Terbang Utara, the island claimed by the residents of Amaya. A paucity of appropriate resources and technology prevents people in Amaya from maintaining a constant surveillance of their island territory. While disturbed and frustrated by the actions of people in Wulur, Mayawo nevertheless do not regard the defence of their territorial integrity as a matter of economic concern or imperative; the coastal and terrestrial area claimed by Amaya is easily twice that owned by Wulur. Rather, it is for them a matter of cosmological and ontological importance. 
In 1986, armed with the resolve to end the dispute once and for all (and with spears, bows and arrows) the people of Amaya travelled to Wulur. The dispute, for them, would be resolved in terms of its own logic - that is, in terms of the dictates of "tradition" (adat), grounded as it is in local narratives and the cultural geography. In order to do this, according to local adat, the parties concerned are required to drink locally brewed palm spirit (arko) together. Apparently, in this context, the brew has the capacity to distinguish right from wrong, truth from fiction. The offenders identified in this way are immediately struck down and die a rather painful death. People in Wulur declined to participate in this ceremony. Their refusal resulted in a declaration of war by the residents of Amaya. The situation became so inflamed that the police were called in from the neighbouring island of Kisar, supposedly to control hostilities.

The two men who arrived by motor launch were reluctant to take sides and, after half-heartedly threatening the warring parties with imprisonment if they did not desist with hostilities, quickly departed. The outcome of this official intervention? The people of Amaya returned to the other side of the island, the position of the boundary is still in dispute, the residents of both villages continue to menace each other albeit from afar, and the island of Terbang Utara continues to be visited on a regular basis by the inhabitants of Wulur for the express purpose of poaching trochus shell.

So what are we to make of this incident? It is apparent that local narratives signify different things for different people. These different significations are actively created by the operation of a number of social processes which variously function to fragment, reduce and dilute the status of these stories (de Certeau 1984:125). By this I mean that the stories become fragmented through their application in a range of diversified social contexts in which there are a number of different and alternative authoritative references. The "excommunication" of ancestral figures, the deconsecration of place, and the construction and extension of neutral areas devoid of the traces of ancestral actions further serves to fragment the narratives. The reduction or miniaturization of the significance of these stories to the point where they apply to only a small group, or at most to one village, further influences their transportability and social import. Finally, the inclusion of other stories within the framework of local narratives gives these narratives a polyvalent status so that their significance changes according to the identity of the groups in which they circulate.

In terms of the dispute, this means that the police (and the local traders) dismiss these narratives as curious and somewhat fantastic fictions, the significance of which pertains only to the level of the village. Their actions are informed by other discourses, namely those tied up with, and empowered by, the state and the market-place. For the local traders and the police the landscape is not imbued with the noumenal, toponymic activities of the ancestors. Rather, 
it is excommunicated from these associations, deconsecrated of its cultural meanings and generally neutralized in the process of constructing it firstly as an economic resource and secondly as an administrative area.

The residents of Wulur, however, are caught between the logic of local narratives and the seduction of national and economic myths. Constructed as a commodity, and a recent one at that, trochus shell is not seen to fall within the province of objects encompassed and controlled by local narratives. Trochus shell as a commodity is thus not regarded by Wulur residents as an adat-defined thing. The implication of this is that the meaning of the landscape as an economic entity is increasingly emphasized above and beyond its other meanings in terms of identity, relatedness and cosmology. The imperative to disassociate objects and adat in this way and, by extension, people and place, is largely provided by the commodity context on Damer, which is primarily structured by the Indonesian-Chinese traders and their actions. In this connection Wulur is both home and headquarters for their activities and, in the light of this, it is not surprising that the commodity context is most acutely accentuated in this village.

The assertion by people in Wulur, however, that the boundary between the domains of Wulur and Amaya lies elsewhere clearly points to the fact that the value of local narrative has not been totally dismissed and, indeed, suggests an engagement, albeit selective, of these very narratives. What appears to have happened, though, is that in their argument with the residents of Amaya, people in Wulur have miniaturized the significance of the narrative so that it only relates to the particular group in Wulur for whom the narrative represents a founding "topostory" and they have chosen instead to valorize other narratives. In Amaya, the opposite of this has occurred. To some extent, this process of reduction can be understood in terms of the heterogeneity of the population of Wulur. Wulur, perhaps more than any other village on the island, is home to a large number of immigrants (pendatang) who originate elsewhere in the region. For these people local narratives of place and the cultural geography itself do not hold the same meanings as they do for indigenous residents. In the context of the boundary dispute, however, indigenous residents would seem to have selectively chosen to distance themselves from their collective memories - a form of social amnesia perhaps.

The appropriation and appropriateness of narrative for authorizing social action is thus contextual. This is clearly demonstrated in the dispute between Wulur and the village of Kehli over the ownership of Terbang Selatan. In this case, the residents of Kehli claim ownership on the basis of long-term residence on, and association with, the island. The inhabitants of Wulur, however, emphasize the inalienability of their attachment to the island by citing the same narrative which they choose to play down, even forget, in their argument with Amaya. It would seem then that where other authorizing references exist that 
best suit the situation and interests of those concerned, local narratives are deemphasized in terms of their function as spatial legislation. The assertions of Wulur residents regarding the "true" position of the boundary, assertions motivated by the desire to maximize their economic interests, suggests that this is exactly what has happened. The legislative effectiveness of these other discourses is perhaps best demonstrated by the fact that Wulur residents continue to poach trochus shell.

The people of Amaya are the "true believers" in this context. Local narratives are more than "just so" stories and, notwithstanding the thrust of Christianity and Indonesian nationalism, they still represent the primary epistemological forms by which place is engaged in the production of social identity and in the reproduction of a theory of practice. In the context of their dispute with Wulur, they resist the processes of fragmentation and miniaturization, and work to maintain the univalent (and universal) status of their stories. The position adopted by immigrants in Amaya is thus quite different from the one advocated by pendatang in Wulur. In the former case, it is in people's interest to support and, indeed, memorize, the content and meaning of local narratives. In doing so, they firmly anchor themselves within the social landscape and establish a common ground on which to claim rights, responsibilities and relationships. It is this common ground - the cultural geography with all its attendant meanings and significations - which people in Amaya choose to emphasize above and beyond the designation of land as an economic base. Yet increasingly, as the recalled incident suggests, Mayawo stories are called upon to compete with a number of other discursive forms. Removed from their immediate referential topos and launched into this orbit of competition and abstraction, they circulate as fluid signs often subject to revision, ridicule and rejection.

\section{Conclusion}

In this paper, I examine the relationship between stories, people and the landscape. At one level, Mayawo narratives can be regarded as epistemological maps insofar as they constitute a theory of knowledge about the landscape as an ordered plane of named and pre-established places. In this sense then, the cultural geography represents the state of this knowledge and the field in which the production and reproduction of this theory takes place. This is done through the movements and displacements individuals effect when they act upon place and transform it into space. Mayawo narratives are thus also itineraries of practice in the same way that the landscape, when acted upon, becomes a text for conduct. Both delineate fields of operations and function to spatialize people's actions. Thus the cultural geography, and the narratives that make it, are simultaneously both map and itinerary, and in this sense they coincide with Ricoeur's distinction between the "reproductive" and "productive" imagination (1986). When both the cultural geography and local stories are no longer accorded this status or 
acted upon accordingly, or when itinerary is privileged to the point where the map is made redundant, or when the map itself is subjected to analysis and casuistry, then alienation and ambiguity arise. There is no longer a play of changing relationships between places and spaces, between maps and itineraries: the poetics of place succumb to the politics of space.

\section{References}

Certeau, Michel de

1984 The practice of everyday life. Berkeley and Los Angeles: University of California Press.

Corbin, Henry

1969 Creative imagination in the Sufism of Ibn 'Arabi. Princeton: Princeton University Press.

Geertz, Clifford

1973 The interpretation of cultures: selected essays. New York: Basic Books.

Pannell, Sandra

1989 Carving the palm: the role of metaphor in Mayawo marriage rituals. Mankind 19(3):160-170.

1990 Now we follow "Our Father": Christianity, colonialism and cultural transformation on the island of Damer, Maluku Tenggara. Cakalele $1(1 / 2): 27-47$.

1991 Narrative boundaries, national horizons: the politics of identity in Amaya, Maluku Tenggara, Indonesia. PhD thesis, The University of Adelaide.

1992 Journeys to other worlds: narratives of headhunting, appropriation and the Other in the "Eastern Archipelago". Oceania 62(3):162-179.

Ricoeur, Paul

1986 Lectures on ideology and Utopia. New York: Columbia University Press.

Sahlins, Marshall

1981 Historical metaphors and mythical realities: structure in the early history of the Sandwich Islands kingdom. Ann Arbor: University of Michigan Press.

Schneider, David

1984 A critique of the study of kinship. Ann Arbor: University of Michigan Press. 


\section{Notes}

1 A draft of this paper was presented at the Australian Anthropological Society Conference, 30 September-2 October 1992, in the session entitled "The Poetic Power of Place" convened by Professor James Fox. I would like to acknowledge the contribution of Daniel Vachon to the writing of this paper and his insightful comments regarding the constitutive significance of place. Barbara Grimes also offered her support for this reconsideration of the social importance of place.

2 Unlike Geertz's (1973) notion of cultural patterns as models of and models for "reality", with its attendant implications of circularity and stasis, Ricoeur's (1986) conceptualization of the social and cultural imagination as both reproductive and productive allows for, indeed is predicated upon, creativity and change.

3 In my previous writings on Damer, I have variously spoken of Mayawo narratives as "myth" (Pannell 1989, 1990) and "history" (Pannell 1991, 1992). The latter designation constitutes the preferred term in more recent accounts. This preference was informed by Mayawo use of the Indonesian term sejarah as a gloss for the indigenous term for local narratives - hynero. The term sejarah is commonly and widely interpreted in English as meaning, or as referring to, "history". While the appellation "history" might be an appropriate gloss for sejarah, in the light of my current reconsideration of Mayawo social forms and cultural logic, it now seems an unsuitable term to describe and denote the narratives I refer to in this paper. The construct topogeny, or even the neologism "topostory", appears more suited to delineating the content and concepts of the narratives. I should add that local usage of the term sejarah is not inconsistent with this view and is more probably a reference to the perceived veracity and empirical nature of local narratives than it is to the form that they take.

4 Readers familiar with my previous work on Mayawo social organization and social relatedness will note that the present discussion represents a considerable conceptual re-orientation to the original ethnographic data. Somewhat reminiscent of David Schneider (1984), recent questioning and, indeed, rejection of the traditional paradigm of kinship and social organization studies (which pervades the anthropological literature pertaining to eastern Indonesia) has resulted in a radically different understanding of the material. Accordingly, the present discussion represents but a brief allusion to a current and more considered re-analysis of place and its logical significance in the construction of "kinship" and social organization in Amaya. 